\title{
等角写像の折紙への応用* (巻き取り可能な円形膜作成法)
}

\section{石田 祥子 ${ }^{* 1}$, 野島 武敏 ${ }^{* 2}$, 萩原 一郎 ${ }^{* 3}$ \\ Conformal Transformation and Application to Origami Designing (New Method to Generate Crease Patterns of Foldable Circular Membranes)}

\author{
Sachiko ISHIDA ${ }^{*}$, Taketoshi NOJIMA and Ichiro HAGIWARA \\ ${ }^{* 1}$ Meiji University, Meiji Institute for Advanced Study of Mathematical Sciences \\ 1-1-1, Higashi Mita, Kawasaki, Kanagawa, Japan
}

This paper presents a new method using conformal transformation to obtain crease patterns of foldable circular membranes by wrapping around a center. This method enables to design complex structures systematically and efficiently from simple structures, controlling angles among fold lines for maintaining significant advantages of origami foldable and developable at will. It is shown that not only existing designs of foldable circular membranes, which are wrapped up and shaped as regular polygons, and also new designs, which are shaped as polygons with different sides or angles like a rectangle or a diamond shape, are successfully produced by the method. For foldable membranes to radial direction, the new method is more flexible to the designing of zigzag fold lines than the previous method by mirror image, since zigzag fold lines can be generated close to the center of membranes without geometrical constraint. Properties of the produced membranes are discussed in the paper.

Key Words : Origami, Modeling, Structural Design, Foldability, Membrane, Conformal Transformation, Numerical Simulation

\section{1. 緹}

近年，野島らによって折り畳み・展開が自由自在な平面・円筒・円錐・球等の構造物 ${ }^{(1)-(7)}$ が報告された。この ような折り畳夕性能をもつ構造物の創生には，折線の成す角度によってその機能性および造形美が決定されるた め, 角度の設計が非常に重要である。これらの折り畳みの研究はそれぞれの形状に対して折線の成す角度の設計 を行っており, 構造物の形状間の関連性についてはふれられてはいない. よって, 設計者にとって手間と時間が かかるものであった.

石田らは，等角写像変換を用いることによってそれぞれの構造間を関連付けられるのではないかと考えた．等 角写像変換とは, 変換の前後で任意の 2 線分がな寸角度が保存されるという特性を持つため, 折り畳み構造物の 設計には非常に都合がよく, あらかじめ比較的簡単な構造物で設計を行っておけば, 数学的変換によって構造物 の機能性や造形美をそのままに, 複雑でかつ精緻な構造物へと派生させることができる. 新規の構造物を創造す ることも可能であり，ひとつひとつの形状で設計を行うよりも容易であり効率化が図られる．すでに石田らは等 角写像変換のうち渦系の流れの変換を用いて, 円筒構造物展開図から折り畳夕可能な円錐殼構造物展開図および 円形膜が作成可能であることを示し， 円錐款構造物について詳細な解析を行った ${ }^{(8)}$. 本報では，同様に渦系の流 れの変換を用い，巻き取り可能な円形膜を作成するための条件式を明確にし，得られた円形膜の分類および特性

\footnotetext{
${ }^{*}$ 原稿受付 2012 年 11 月 7 日

*1 明治大学先端数理科学インスティチュート（†214-8510 神奈川県川崎市多摩区東三田 1-1-1）

*2 正員, アート・エクセル折紙工学研究所 (†573-1112 大阪府枚方市楠葉美咲 2-6)

*3 正員, フェロー, 明治大学先端数理科学インスティチュート

E-mail: tz12013@meiji.ac.jp
} 
についてまとめる.

折紙は様々な工学分野で研究され，宇宙産業では巨大かつ高剛性の宇宙構造物を地球上で製造し宇宙空間に運 搬し展開・構築するという折紙の幾何学的特性に基づいた革新的アイデアは関係者に大いなる刺激を与えた (9)(11). また民間用では，折り盢み構造はエネルギー吸収量の観点から塑性座屈モデルの研究にも用いられ，自動車産業 や鉄道産業への応用 ${ }^{(12)-(14)}$ も期待される. さらに身近な例としては, 地図の折り畳み ${ }^{(11)}$, 折り畳み可能な容器の製 造(1), テント等の大きな構造物の収納 ${ }^{(2)}$ 等, 応用例は枚挙にいとまがない. 数学的変換を行うことによって上述の 様々な構造を誰でもシステマティックに得ることができるようになれば，折紙の機能性を活用した構造物はより 深く一般に浸透し，親しまれるようになるであろう.

\section{2. 等角写像法}

\section{$2 \cdot 1$ 本報で取り扱う等角写像変換}

等角写像とは, 2 つ座標系 $\xi-\eta$ 座標系と $x-y$ 座標系において, $\xi-\eta$ 座標系における任意の $2 つ の$ 線を $x-y$ 座標系 に変換するとき, 変換の前後において $2 つ の$ 線のな寸角が等しく保たれる写像をいう ${ }^{(15)}$. 図 $1(\mathrm{a})$ に示寸一様流孔 $\varsigma=\xi+i \eta$ と図1(b)に示寸渦系の流れ $z=x+i y$ の間の変換式は次式である.

$$
\varsigma=i \cdot k \log z
$$

ここで, $k$ は定数である. 変換前後の速度ポテンシャルの等高線 $(\Phi=$ const. $)$ および流線 $(\Psi=$ const. $)$ を折り線として置き 換えることによって, 既知でシンプルな折紙展開図をあらかじめ作成しておき(図 1(c)), それに対して変換を行い, 円形膜 を得ることを目指寸(図 1(d)). また, 等角写像変換を折紙こ応用する利点として, 変換の前後で図形の角度が保存されると いう点がある. 折り畳み構造物の設計では工学的分野への適用を考える際, 角度によって折り畳みの特性が変化するため角 度の設計が重要になる場合が多い. よって, 変換前に設計した角度がそのまま変換後も保存されるのは非常に都合がよい.

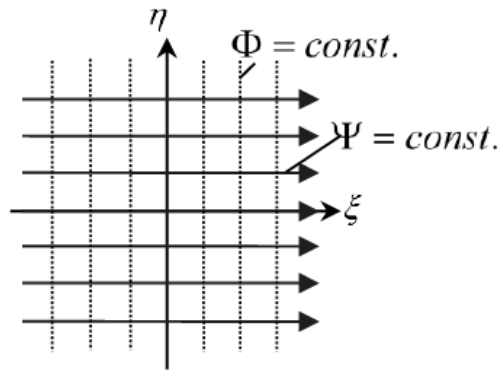

(a) $\xi-\eta$ plane

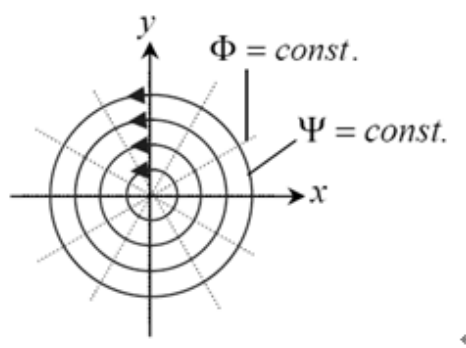

(b) $x-y$ plane

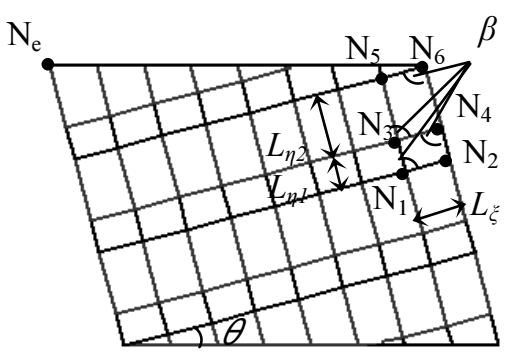

(c) $\xi-\eta$ plane

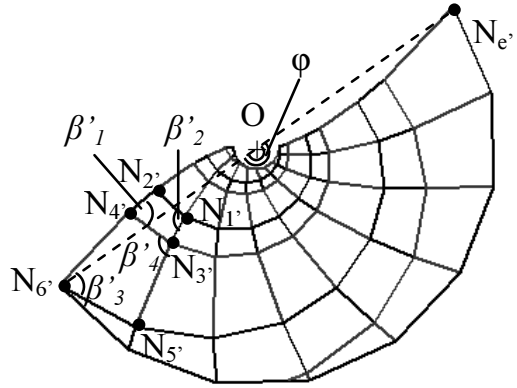

(d) $x-y$ plane

Fig. 1 Conformal Transformation on Fluid Flows and Analogy to Origami Patterns. (a): Uniform flow. (b): Rotational flow around the center. (c): Original crease pattern for cylindrical shell. (d): Crease pattern for conical shell given by the transformation of eq. (1) from (c) . 


\section{$2 \cdot 2$ 定式化}

図 1(d)に示した平面紙(展開図)では外周部を除き，各々の節点には 4 本の折線が集まっている. 本報では，4本の折線で 平面紙を折り曲げて新たな平面上へと折り畳むことに焦点を当てる. そのためには, 任意の節点に集まる 4 本の折線のなす 角度がある条件(向かい合う角度の和が $\pi$ )を満足していなければならない. 以下，乙れを折り畳子(平坦折り)条件と呼ぶ. 前節で述べた通り, 等角写像変換では変換の前後において, 任意の 2 つ線のなす角が等しく保たれる.つまり, 変換前に, 折り畳夕条件を満足していれば, 変換後も折り畳みの条件を満足するはずである. しかしこれは変換後の折線が曲線となる ことを許容した場合においてである. 本報では，折り畳夕に焦点を当てるため折線は直線に限定する. 折線を変換するので はなく節点座標を変換し, 変換後の節点を変換前の節点の関係と同様に線分で結ぶものとする.つまり, 変換前に山折り線 で結ばれている節点は山折り線で, 変換前に谷折り線で結ばれている節点は谷折り線で結ぶ. このとき, 角度は厳密に保存 されないため, 変換後の展開困において折り畳み条件を満たすよう立式する.

2 種類の平行四辺形要素が 1 段違いに配置された図 1(c)に示す円筒構造物展開図を考える. この円筒構造物展開図は $\theta$ 傾 いており, 展開図の右端こおいて 2 段の上昇がある. この上昇段数を $D$ と置く. 2 種類の平行四辺形要素をなす節点を $\mathrm{N}_{1}$ $\sim \mathrm{N}_{6}$, 角度 $\mathrm{N}_{2} \mathrm{~N}_{1} \mathrm{~N}_{3}\left(=\mathrm{N}_{3} \mathrm{~N}_{4} \mathrm{~N}_{2}\right)$ および角度 $\mathrm{N}_{4} \mathrm{~N}_{3} \mathrm{~N}_{5}\left(=\mathrm{N}_{5} \mathrm{~N}_{6} \mathrm{~N}_{4}\right)$ を $\beta$, 横方向の辺の長さを $L_{\xi}$, 縦方向の辺の長さを $L_{\eta 1}$ および $L_{\eta 2}$ とする. 図 1(c)は渦糸の流れの変換式(1)によって図 1(d) へと変換される. ここで, $k=1$ とした. 節点 $\mathrm{N}_{1} \sim \mathrm{N}_{6}$ はそれぞ

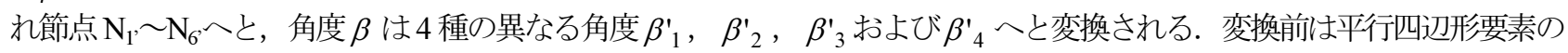
配列であったため, 角度 $\beta$ とその補角 $\pi$ - $\beta$ のみを考慮すればよかったが, 変換後の要素は向かい合う辺の平行性が失わ れるため, 変換された角度 $\beta^{\prime}{ }_{1} \sim \beta^{\prime}{ }_{4}$ は一般的にすべて異なる. 変換前の要素が合同であった場合, 変換後の要素は全て相 似形となることが文献(8)に示されているので，変換後のある節点で折り畳みの条件が成り立てば残りの任意の節点におい ても折り畳みの条件が成り立つことは自明である. 図 1(c)は 2 種類の合同な要素から成るので, 図 1(d)は 2 種類の相似な四 角形群から成る. よって全ての節点において折り畳みの条件がなりたつためには, 代表して節点 $\mathrm{N}_{1}$,および $\mathrm{N}_{3}$, において, そ れぞれ折り畳みの条件を満たすことと同值である. 節点 $\mathrm{N}_{1}$ てでの折り畳多の条件は, $\beta^{\prime}{ }_{2}+\beta^{\prime}{ }_{3}=\pi$ である ${ }^{(1)} .0<\beta^{\prime}{ }_{2}, \beta^{\prime}{ }_{3}<\pi$ として次式で書き換えられる.

$$
\cos \beta_{2}^{\prime}+\cos \beta_{3}^{\prime}=0
$$

同様に，節点 $\mathrm{N}_{3}$,において折り畳みの条件は次式となる.

$$
\cos \beta_{1}^{\prime}+\cos \beta^{\prime}{ }_{4}=0
$$

変換式(1)により, 変換後の角度 $\beta^{\prime}{ }_{1} \sim \beta^{\prime}{ }_{4}$ は変換前の幾何変数 $\beta, \theta, L_{\xi}, L_{\eta 1}, L_{\eta 2}$ を用いて次式で表される.

$$
\cos \beta_{1}^{\prime}=\frac{c_{1}(1,1)-c_{1}(0,1) \cdot e_{1}(1,0)-c_{1}(1,0) \cdot e_{1}(0,1)+e_{1}(1,1)}{\sqrt{1-2 c_{1}(0,1) \cdot e_{1}(0,1)+e_{1}(0,2)} \sqrt{1-2 c_{1}(1,0) \cdot e_{1}(1,0)+e_{1}(2,0)}}
$$

$$
\cos \beta^{\prime}{ }_{2}=\frac{c_{1}(1,1) \cdot e_{1}(1,1)-c_{1}(1,0) \cdot e_{1}(1,0)-c_{1}(1,0) \cdot e_{1}(0,1)+1}{\sqrt{1-2 c_{1}(0,1) \cdot e_{1}(0,1)+e_{1}(0,2)} \sqrt{1-2 c_{1}(1,0) \cdot e_{1}(1,0)+e_{1}(2,0)}}
$$

$$
\cos \beta^{\prime}{ }_{3}=\frac{c_{2}(1,1)-c_{2}(0,1) \cdot e_{2}(1,0)-c_{2}(1,0) \cdot e_{2}(0,1)+e_{2}(1,1)}{\sqrt{1-2 c_{2}(0,1) \cdot e_{2}(0,1)+e_{2}(0,2)} \sqrt{1-2 c_{2}(1,0) \cdot e_{2}(1,0)+e_{2}(2,0)}}
$$

$$
\cos \beta^{\prime}{ }_{4}=\frac{c_{2}(1,1) \cdot e_{2}(1,1)-c_{2}(1,0) \cdot e_{2}(1,0)-c_{2}(1,0) \cdot e_{2}(0,1)+1}{\sqrt{1-2 c_{2}(0,1) \cdot e_{2}(0,1)+e_{2}(0,2)} \sqrt{1-2 c_{2}(1,0) \cdot e_{2}(1,0)+e_{2}(2,0)}}
$$

ここで $c_{1}(m, n), \quad c_{2}(m, n), \quad e_{1}(m, n)$ および $e_{2}(m, n)(m=0,1,2, \ldots, n=0,1,2, \ldots)$ は次式で表される.

$$
c_{1}(m, n)=\cos \left[\frac{-m \cdot L_{\xi} \cos \theta+n \cdot L_{\eta 1} \cos (\beta+\theta)}{k}\right]
$$




$$
\begin{aligned}
& e_{1}(m, n)=\exp \left[\frac{m \cdot L_{\xi} \sin \theta+n \cdot L_{\eta 1} \sin (\beta+\theta)}{k}\right] \\
& c_{2}(m, n)=\cos \left[\frac{-m \cdot L_{\xi} \cos \theta+n \cdot L_{\eta 2} \cos (\beta+\theta)}{k}\right] \\
& e_{2}(m, n)=\exp \left[\frac{m \cdot L_{\xi} \sin \theta+n \cdot L_{\eta 2} \sin (\beta+\theta)}{k}\right]
\end{aligned}
$$

変換先の $x-y$ 平面での原点を $\mathrm{O}$, 節点 $\mathrm{N}_{\mathrm{e}}$ の変換節点を $\mathrm{N}_{\mathrm{e}}$ として, 変換によって得られた扇形の展開図が円形と なるための条件は中心角 $\varphi=\angle N_{6^{\prime}} O N_{e^{\prime}}=2 \pi$ である. この条件は変換式(1)により次式で表される.

$$
\frac{N L_{\xi} \sin \beta}{k \sin (\theta+\beta)}=2 \pi
$$

ここで， $N$ は水平方向もしくは段上昇 $D$ によって角度 $\theta$ 傾いた折線方向の要素数である. また，図形の連続性か ら上昇角 $\theta$ は離散值をとり, 次式が成り立つ.

$$
N L_{\xi} \sin \theta-D \frac{L_{\eta 1}+L_{\eta 2}}{2} \sin (\beta+\theta)=0
$$

ここで簡単のため, $L_{\eta 1}$ と $L_{\eta 2}$ で 1 対となるよう， $D$ は偶数とする. 式(4)〜 (7)を式(2)および式(3)に代人すると， 式(2)および式(3)は変換前の幾何変数 $\beta, \theta, L_{\xi}, L_{\eta 1}, L_{\eta 2}$ の関数として表される. ここで, $\beta$ を固定值とし て与え, 4 式(2), (3), (12)および(13)を連立して解くことにより, 円形膜作成に必要な幾何変数 $\theta, L_{\xi}, L_{\eta 1}, L_{\eta 2}$ を得ることができる．連立方程式は非線形であるため，ヤコビ行列を求め反復法で数值的に解く.

\section{3. 変換結果と考察}

渦糸の流れの変換式(1)によって得られた円形膜を示す. 以下，展開図の山折線を実線，谷折線を破線で示す.

\section{$3 \cdot 1$ 正多角形に巻き取られる円形膜}

$L_{\eta 1}=L_{\eta 2}$ と限定した場合には, 文献(7)に報告されているように正多角形状に巻き取られる円形膜が生成される.この時, 変換前の展開図の要素は全て合同であるから, 渦糸の流れの変換後の要素は全て相似形となる ${ }^{(8)}$. 段上昇数 $D$ と同数の螺旋 が円形膜外周から円形膜中心向かって等間隔に配置される. 巻き取り後の形状は螺旋の本数に依存し, 任意の螺旋本数で 巻き取られる.つまり，図2(a)，(d)および(g)から得られた図2(b)，(e)および(h)はそれぞれ螺旋本数が 2 本，3 本，16本で あるので，巻き取り後の形状はそれぞれ線分状(図 2(c))，正3 角形状(図 2(f)), 正 16 角形状(図 2(i)) となる. コンパクトに巻 き取られ，一軸方向に引つ張り/圧縮することにより展開/収縮が自由自在である(図 2(j) (l)).

\section{3 -2 不等分な辺長を持つ多角形状に巻き取られる円形膜}

$L_{\eta 1} \neq L_{\eta 2}$ とすると変換前の展開図において縦方向の折線間隔を不等分に配すことができる. $L_{\eta 1}<L_{\eta 2}$ とし $L_{\eta 1}$ と $L_{\eta 2}$ を交互に配置すると，変換後は円形膜外周から円形膜中心的向から螺旋の間融長短交互になり，巻き取り後も長短 2 つの辺長をもつ多角形となる. 図3(a)から変換によって得られた図3(b)は4本の不等分配された螺旋からなり，巻き取り後 は長方形となる(図3(c)). さらに長短の差を増すと, 図3(f)に示すように, 非常に扁平な長方形となる. 図3(i)および(l)も扁 平な多角形の例であり，長短の辺長を交互に持つ六角形および八角形である. それぞれ一見すると正三角形および正方形に 見え，正多角形の角を面取りしたような形状を得ることができる. 短い辺長が極限 0 となったとき，図3(f)は図 2(c)に示す 線分状への巻き取り, 図3(i)は図2(f)にしめす正三角形状への巻き取りへと縮退する. 同様に, 図 3(l)は正方形状への巻き取 りへと縮退する. 円形膜に用いる材料によってはその厚みを無視することができず, 図 2 のように巻き取ることが困難にな る場合, 図 3 に示すように辺の長さに長短をつけることで, 厚外による巻き取りのずれを緩和するような設計が有効である. また，収納スペースの形状に合わせて巻き取り後の形状を決定し，それに見合った折線を設計する等，より実用的な設計二 
(a)

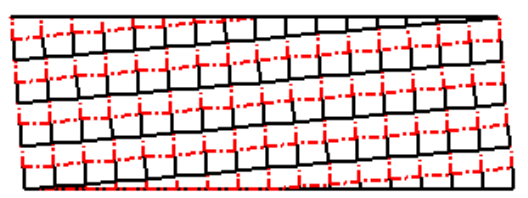

(d)

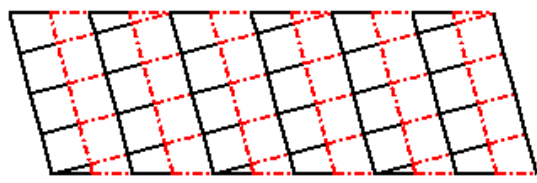

$(\mathrm{g})$

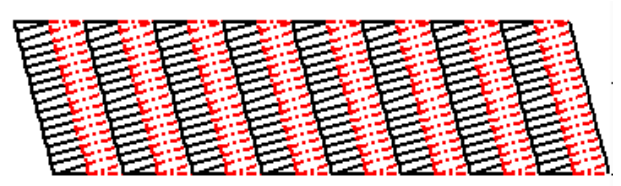

(h)

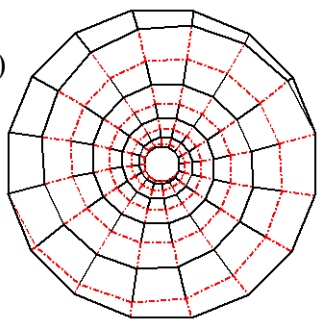

(e)
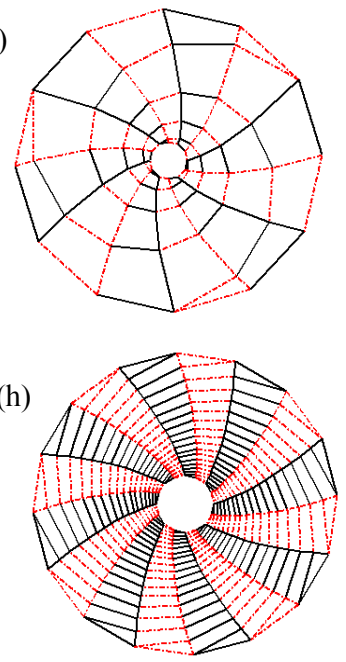
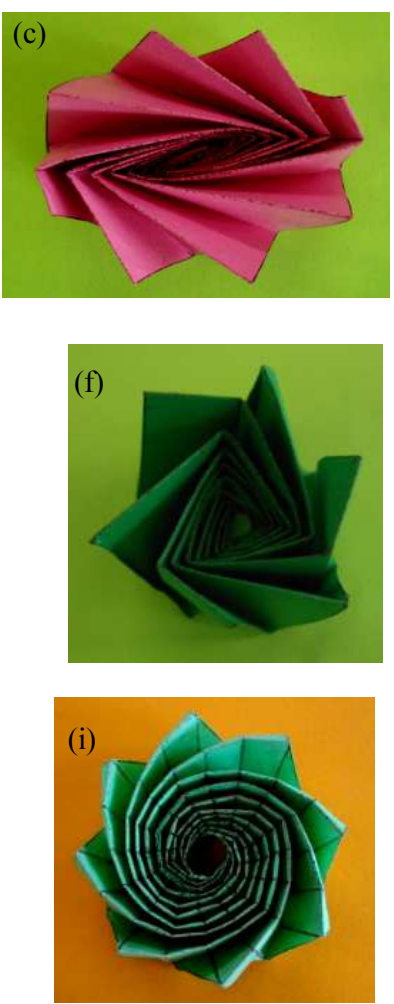
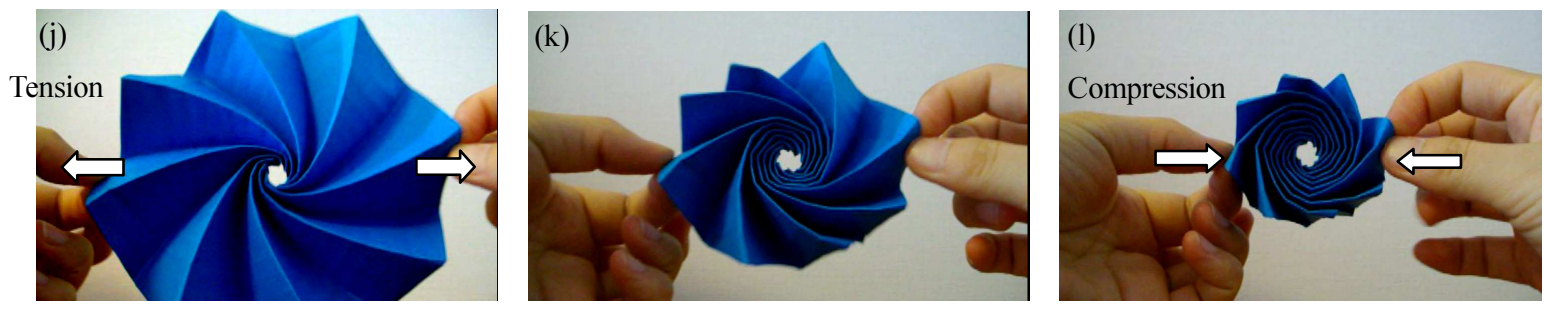

Fig. 2 Crease Patterns and Physical Models of Foldable Membranes. (a), (d) and (g): Original crease patterns. (b), (e) and (h): Transformed crease patterns from (a), (d) and (g), respectively. (c), (f) and (i): Physical models of (b), (e) and (h), respectively. (j), (k) and (l): Wrapping and developing of the circular membrane (i) with $\mathrm{D}=16$.

ーズに対応できる.これらは本報で得られた新しい円形膜である.

\section{$3 \cdot 3$ ジグザグな螺旋から成る円形膜}

$3 \cdot 2$ 節において $L_{\eta 1} \neq L_{\eta 2}$ として得られた 2 種類の要素群のうち, 片方の要素群を左右反転させる. 反転した要素群を図 4(a)に斜線で示寸. この時, $\beta \neq \pi / 2$ の条件のもとで縦方向にジグザグの折線を配することができる. 図中のロおよび○ は同じ角度 $(\beta$ および $\pi-\beta)$ の位置を示寸. 要素の反転により折り畳みの条件式(2)および(3)に用いられる角度を入れ替え る必要があるが, 求めるべき未知数と方程式の数は変わらないので同様の立式が可能である. 変換後の円形膜は半径方向の 折線がジグザグになる(図4(b)). 先と同様, 図中のマークは要素の相似性による同じ角度の位置を示す．変換前に 2 種類の 要素群を縦方向に十分に長く配置すると, 変換後は 2 種類の相似な四角形要素を理論上円形膜中心極限にまて配置でき, す なわち中心近傍にまで半径方向にジグザグな折線を導入することができる. 一方, 野島は鏡像法を用いて半径方向にジグザ グな折線を持つ円形膜を作成する手法について論じている ${ }^{(3)}$. 鏡像法とは円形膜中心からの 2 本の放射線を鏡面とみなし， 折線を光のように入射角と反射角が等しくなるように反射させることによってジグザグの折線を作成する手法である(図 4(c)). この手法を用いると円形膜の中心に近づくにつれ入射角および反射角が $0^{\circ}$ に近づき，円形膜の中心部分に折線の至 らない領域(図 4(c)に斜線で表示)ができることは避けられなかった．等角写像を用いた手法では中心極限にまでジグザグな 折線を導入でき, 理論上鏡像法のような制限はない. よって, 半径方向にジグザグな折線を導入する手法として, 等角写像 
(a)

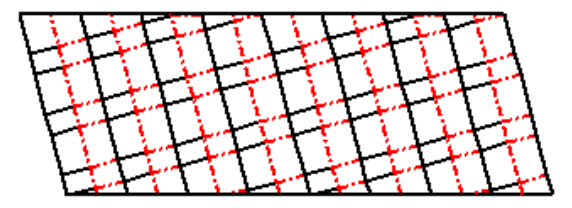

(d)

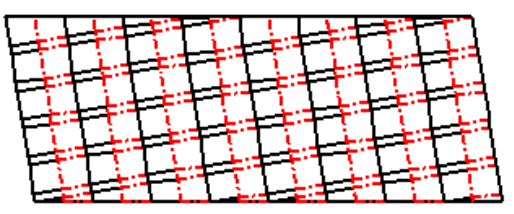

(g)

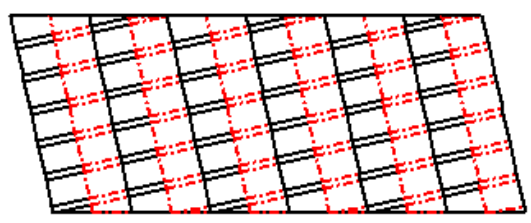

(j)

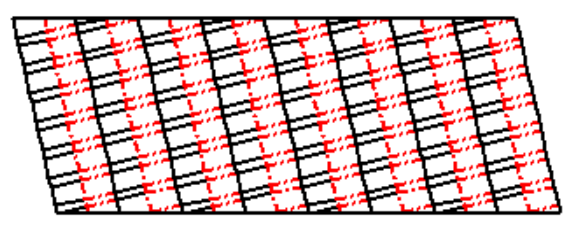

(b)

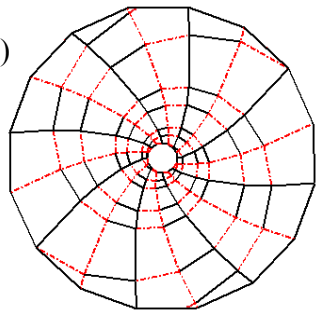

(e)

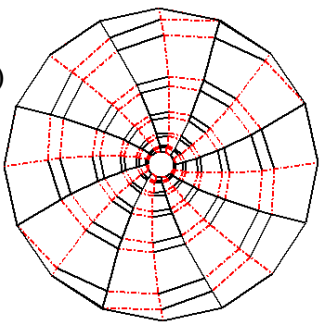

(h)

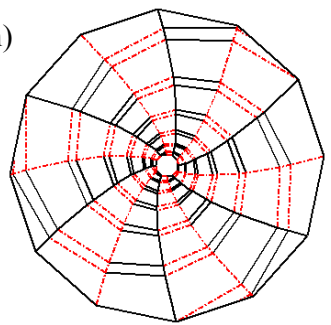

(k)

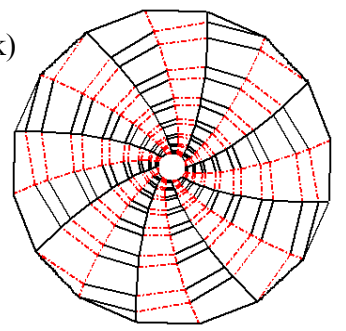

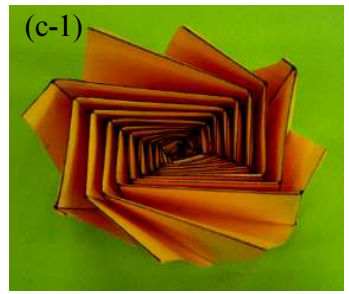
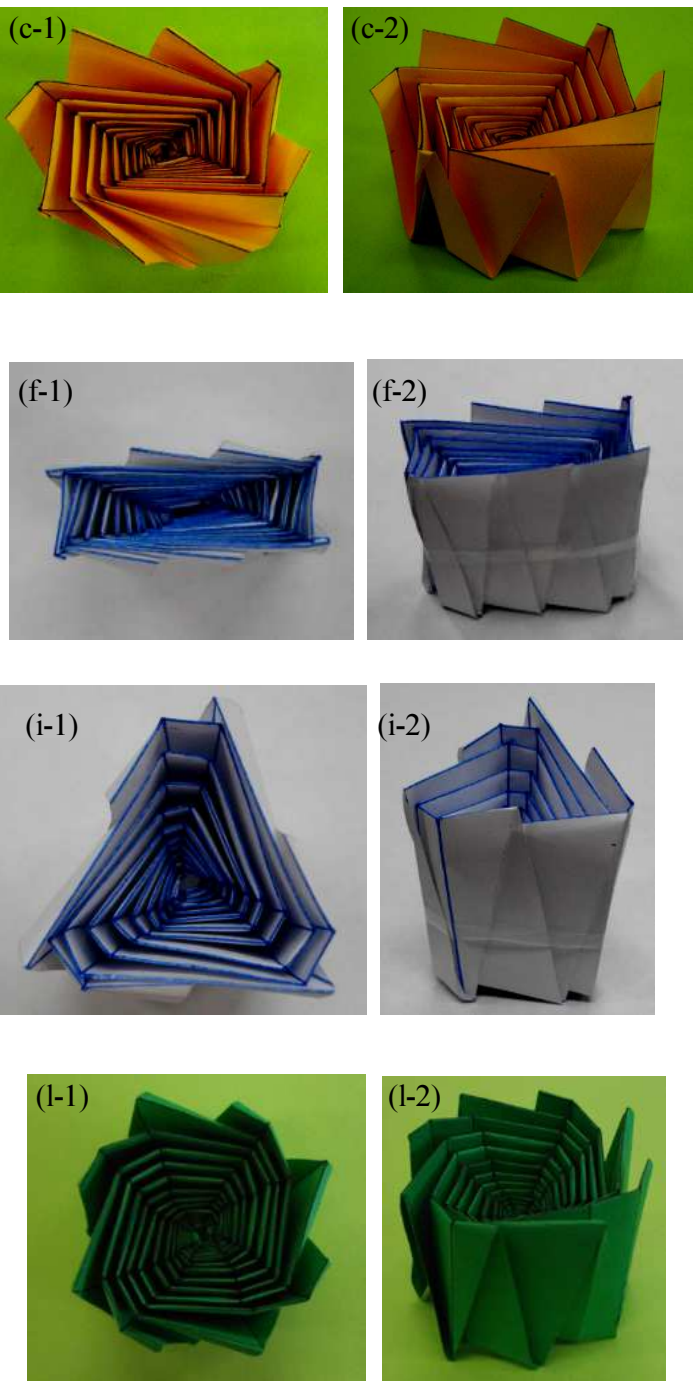

Fig. 3 Crease Patterns and Physical Models of Foldable Membranes. (a), (d), (g) and (j): Original crease patterns. (b), (e), (h) and (k): Transformed crease patterns from (a), (d), (g) and (j), respectively. (c), (f), (i) and (l): Physical models of (b), (e), (h) and (k), respectively.

はより汎用的であると言える. 図4(d)から変換によって得た図4(e)の折紙模型を図 4(f)に示す. 折線が反転するごとに巻き 取りの方向も転するため，一方向への巻き取りではなく，半径方向一収縮するように折り畳まれる.

要素を反転させる代わりに図 $5(\mathrm{a})$ に示すように 2 種類の角度 $\beta_{1}$ および $\beta_{2}$ を縦方向に交互に配置することで, 変換後に半 径方向にジグザグな折線からなる円形膜を作成することもできる. 眓中のマークは同じ角度の位置 $\left(\beta_{1}, \pi-\beta_{1}, \beta_{2}\right.$ およ び $\left.\pi-\beta_{2}\right)$ を示す.ここでは円形膜外周から円形膜中心向から螺旋を等間隔で配置できるよう, 次式を満たすものとする.

$$
L_{\eta 1} \cos \beta_{1}=L_{\eta 2} \cos \beta_{2}
$$

よって, 角度を 2 種類に増やしたが, 未知数の数=方程式の数となる. 先と同様, 変換後は 2 種類の相似な要素群が交互に 配列し, 縦方向に十分な要素数をとることにより半径方向のジグザグな折線を中心まで導入することが可能である(図 5(b)). 図中のマークは要素の相似性による同じ角度の位置を示す。図 5(c)から変換によって得られた図 5(d) の折紙模型を図 5(e) に示す．折線が反転することにより，巻き取りの方向も反転し，半径方向に収縮するように折り畳まれる.

角度 $\beta_{1}$ と $\beta_{2}$ が等しくはないが非常に近い值をとる場合 $\left(\beta_{1} \approx \beta_{2}\right)$, 変換後に巻き取りの方向が反転するに至ら ず, 3 ・ 1 節および $3 \cdot 2$ 節のように 1 方向に巻き取られる構造を作成することもできる. $\beta_{1} \neq \beta_{2}$ であるから変換 
(a)

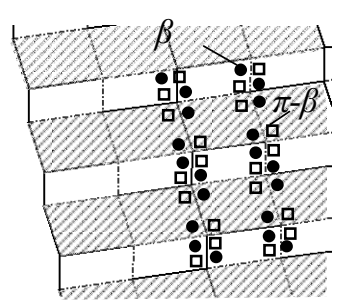

(b)

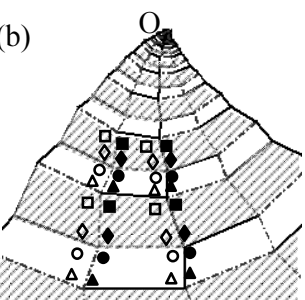

(e)

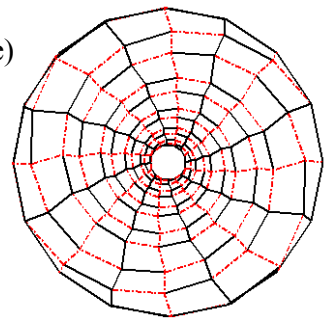

(c)
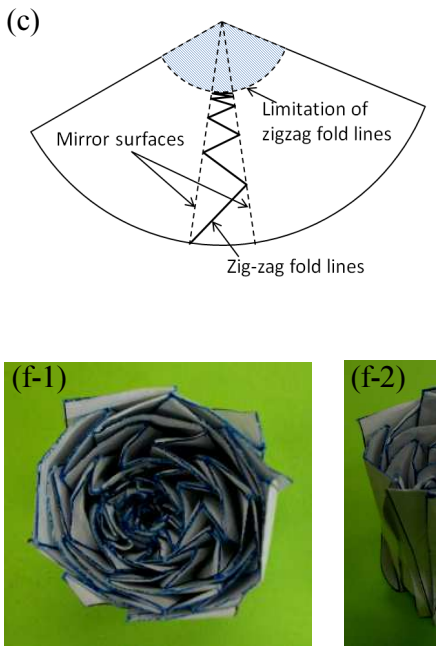

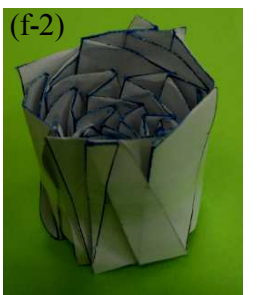

Fig. 4 Definition of Zigzag Fold Lines, Crease Patterns and Physical Models of Foldable Membranes to Radial Direction. (a): Original fold lines. (b): Transformed fold lines from (a). (c): Fold lines by the conventional method by mirroring reported in Reference (3). (d) and (e): Original and transformed crease patterns by the new method. (f): Physical origami model.
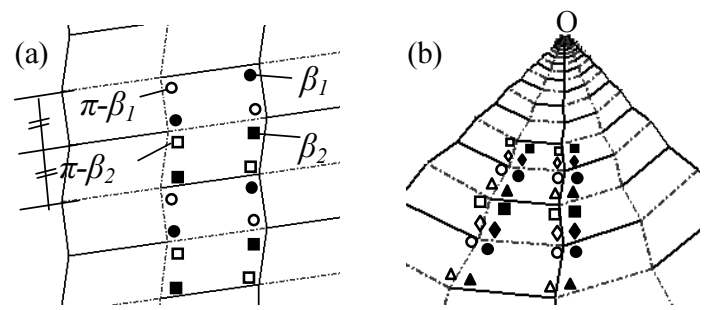

(c)

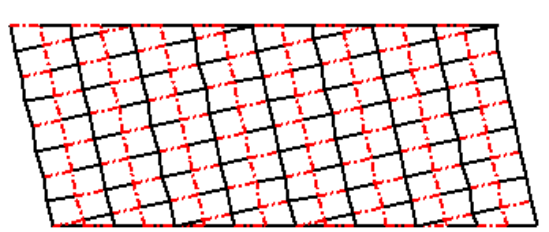

(d)
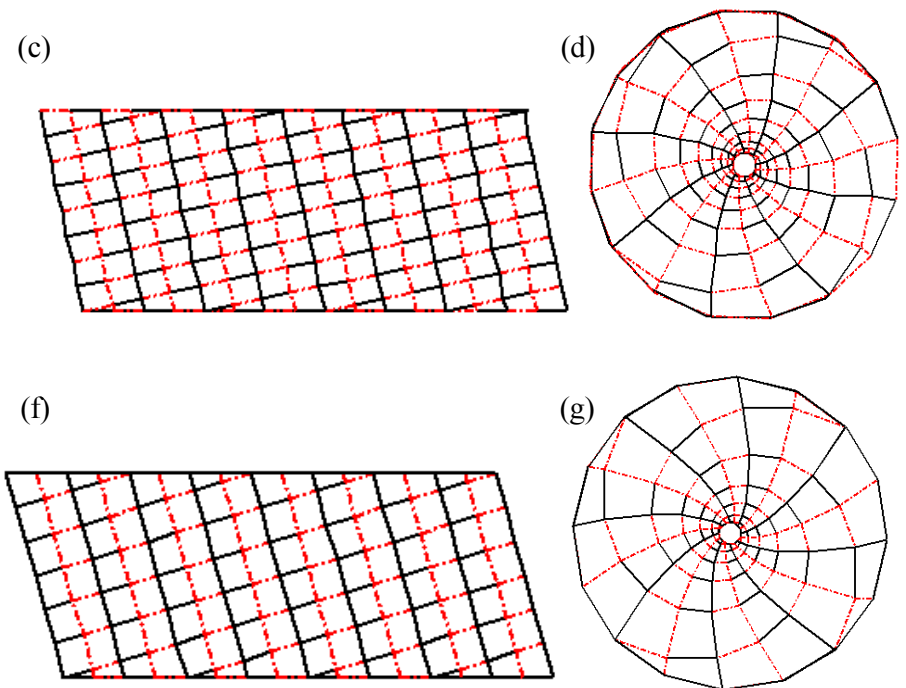

(g)

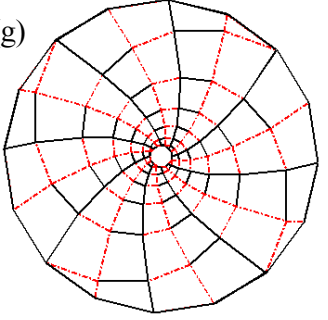

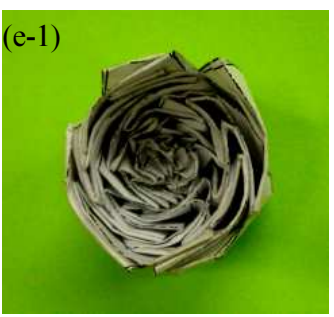
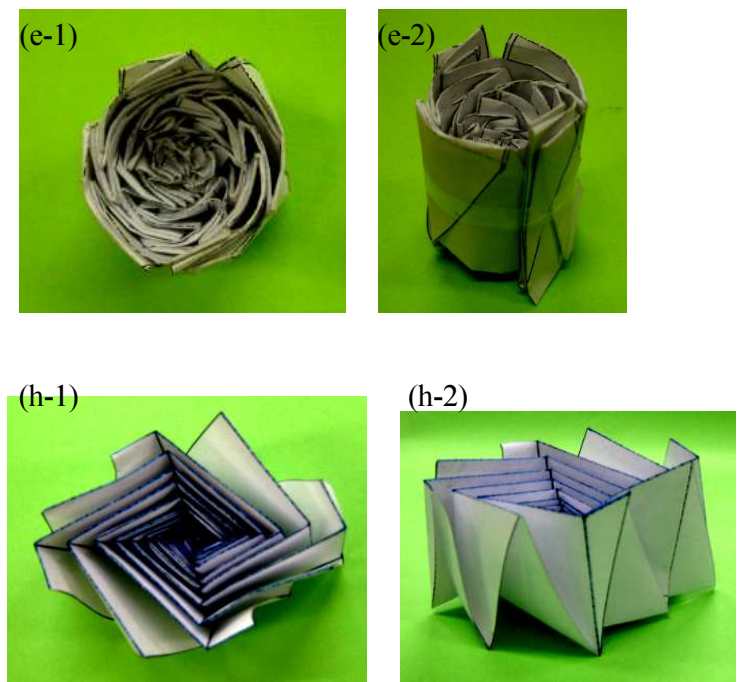

Fig. 5 Definition of Zigzag Fold Lines, Crease Patterns and Physical Models of Foldable Membranes. (a): Fold lines with two angles $\beta_{1}$ and $\beta_{2}$. (b): Transformed fold lines from (a). (c) and (d): Original and transformed crease patterns by the new method. (e): Physical origami model of (d). (f): Original crease pattern with zigzag fold lines. (g): Transformed crease pattern from (f). (h): Physical model of $(\mathrm{g})$. 
(a)

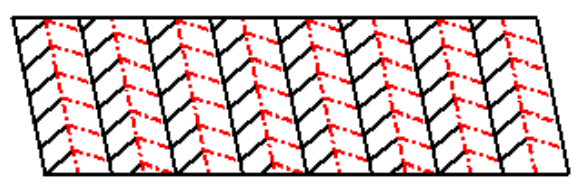

(b)

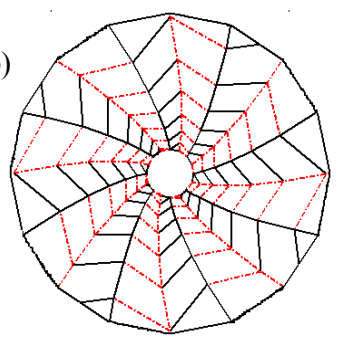

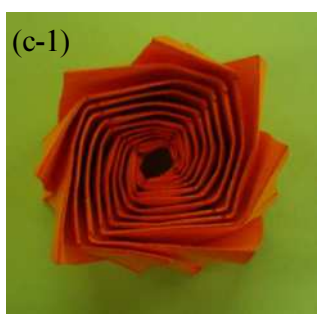

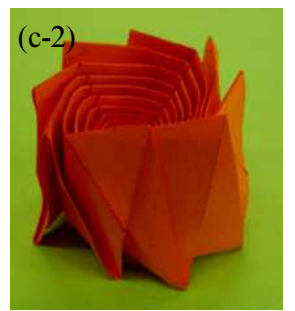

Fig. 6 Crease Patterns and Physical Models of Foldable Membranes. (a): Original crease pattern. (b): Transformed pattern from (a). (c): Physical model of (b).

前は 2 種類の合同な要素群が存在し, 図 5(f)では縦方向の折線は僅かにジグザグである．変換後，図 5(g)では 2 種類の相似な要素群が存在しているが，角度が非常に近いため螺旋は反転していない．よって，1方向に巻き取 られ，また角度の差から巻き取り後の模型は扁平になる．式(14)により螺旋間隔は等しく保たれているので巻き 取り後の形状の辺の長さは等しい. よって, 段上昇 $D=4$ すなわち螺旋本数 4 本の時には菱形を形成する(図 $5(\mathrm{~h})$ ).

同様の議論で未知数の数を増やすことなく, 縦方向ではなく水平方向にジグザグな折線を設けることもできる (図 6(a)). 変換後は $3 \cdot 1$ 節および $3 \cdot 2$ 節と同様, 螺旋まわりに巻き取られ, 螺旋の本数と同数の正多角形を形成 する(図 6(c)). このように, 文献(4)および(7)で論じられた円形膜に対しても, 等角写像を用いて問題なく作成で きる.

\section{4. 結 語}

等角写像変換を折紙展開図作成に応用することにより，既に報告されている円形膜に加え，さらに多様なヴァ リエーションを比較的容易に作成できた．半径方向にジグザグな折線を持つ円形膜では鏡像法を用いると円の中 心付近には折線を生成できないという制限があったが，等角写像による手法ではその制限はなく，より汎用的に デザインできることを示した．また，扁平な形状へ巻き取ることによって，厚みを無視できない材料の使用や収 納スペースの形状に合わせて折線を設計する等, より実用的な設計ニーズにも対応でき, 等角写像による設計手 法の有用性が示された.

このように，等角写像変換は既存の折紙展開図から未だ存在しない折紙構造のイメージを頭の中でふくらませ たり，作成したい折紙展開図のラフスケッチを容易に作ることが可能となる．新たな折紙構造の創生に役立つ手 法となり工学分野への応用が期待できる.

\section{謝辞}

本研究は科研費基盤研究(S)No.20226006「計算力学と折紙工学融合による新しい軽量コア構造の機能創出と製 造法に関する研究」の援助のもとなされた．ここに感謝の意を示す.

\section{文献}

(1) 野島武敏, “平板と円筒の折りたたみ法の折紙によるモデル化”, 日本機械学会論文集 C編, Vol. 66, No. 643 (2000), pp. 1050-1056.

（2）野島武敏，“折りたたみ可能な円錐殼の創製”，日本機械学会論文集 C 編, Vol. 66, No. 647 (2000), pp. 2463-2469.

(3) 野島武敏, “容易な展開を考慮した薄い円形膜の折りたたみ法の折紙によるモデル化”, 日本機械学会論文集 C 編, Vol. 67, No. 653 (2001), pp. 270-275.

(4) 野島武敏, “薄い円形膜の折りたたみ法のモデル化 (等角ら旋様式による折りたたみ法)”, 日本機械学会論文集 C 編，Vol. 67, No. 657 (2001), pp. 1669-1674.

(5) 野島武敏, 亀井岳行, “ら旋状の折り紙で構成された折りたたみ式円錐款の折紙によるモデル化”, 日本機械学会論 文集 C 編，Vol. 68, No. 667 (2002), pp. 1009-1014. 
(6) 野島武敏, “異なる要素形状の組み合わせからなる折りたたみ可能な筒状構造（異型筒及び角錐の折紙によるモデ ル化)”，日本機械学会論文集 C 編, Vol. 68, No. 66 (2002), pp. 1015-1020.

(7) 野島武敏, “展開の容易な円形膜の折りたたみ/巻取り収納法”, 日本機械学会論文集 C 編, Vol. 70, No. 689 (2004), pp. 251-257.

(8) 石田祥子, 亀井岳行, 野島武敏, 萩原一郎, “等角写像とその円錐款折紙構造物設計一の応用”, 日本応用数理学会, Vol. 22, No. 4 (2012), pp. 301-318.

(9) 名取通弘, “展開寸る膜”, 日本機械学会誌, Vol. 102, No. 962 (1999), pp. 48-50.

(10) Guest, S.D., Pellegrino, S., “A New Concept for Solid Surface Deployable Antennas”, Acta Astronautica, Vol. 38, No. 2 (1996), pp. 103-113.

(11) 形の科学会, 形の科学百科事典 (2004), pp. 649-650, 朝倉書店.

(12) 萩原一郎, 山本千尋, 陶金, 野島武敏, “反転らせん型モデルを用いた円筒形折り紙構造の圧潰変形特性の最適化 検討”，日本機械学会論文集 A 編，Vol. 70, No. 689 (2004), pp. 36-42.

(13) 趙希禄, 胡覀波, 萩原一郎, “折紙工学を利用した円筒薄肉構造物の衝突圧潰特性の最適設計”, 日本機械学会論文 集 A 編, Vol. 76, No. 761 (2010), pp. 10-17.

(14) 趙希禄, 胡亜波, 萩原一郎, “折紙工学援用による半割り型自動車サイドメンバーの圧潰エネルギー吸収性能に関 する研究”，日本機械学会論文集 A 編, Vol. 76, No. 767 (2010), pp. 1131-1138.

(15) 今井功, 等角写像とその応用 (1979), 岩波書店. 